\title{
The Electrical Resistance of Rutherford-Type Superconducting Cable Splices
}

\section{S. Heck, C. Scheuerlein, J. Fleiter, A. Ballarino, and L. Bottura} CERN, Geneva, Switzerland

Keywords: Cables, inductance, interconnection, resistance, measurement.

\begin{abstract}
The electrical resistance of Large Hadron Collider main busbar cable lap splices produced by soft soldering has been measured with two independent methods as a function of intercable contact area and for splices made of cables with various defects. For defect-free lap splices, the resistance increases from 0.3 to $10 \mathrm{n} \Omega$ (at $4.3 \mathrm{~K}$ in self-field) when reducing the cable overlap length from 120 to $3 \mathrm{~mm}$, as expected assuming that the resistance is inversely proportional to the intercable contact area.

The resistance of bridge splices that connect side-by-side cables can be predicted from the lap splice resistances and the overlap areas involved.
\end{abstract}

Presented at: ASC 2014, 10-15 August, Charlotte, USA

Geneva, Switzerland

January, 2015 


\title{
The Electrical Resistance of Rutherford-Type Superconducting Cable Splices

\author{
S. Heck, C. Scheuerlein, J. Fleiter, A. Ballarino, and L. Bottura
}

\begin{abstract}
4 Abstract-The electrical resistance of Large Hadron Collider 5 main busbar cable lap splices produced by soft soldering has 6 been measured with two independent methods as a function of 7 intercable contact area and for splices made of cables with various 8 defects. For defect-free lap splices, the resistance increases from 90.3 to $10 \mathrm{n} \Omega$ (at $4.3 \mathrm{~K}$ in self-field) when reducing the cable 10 overlap length from 120 to $3 \mathrm{~mm}$, as expected assuming that the 11 resistance is inversely proportional to the intercable contact area. 12 The resistance of bridge splices that connect side-by-side cables 13 can be predicted from the lap splice resistances and the overlap 14 areas involved.
\end{abstract}

15 Index Terms-Cables, inductance, interconnection, resistance 16 measurement.

\section{INTRODUCTION}

18

, $\mathbf{R}$ UTHERFORD-TYPE cables are widely used for building accelerator magnet coils when the inductance of a magnet 20 wound of a single wire would be too high. An advantage of 21 these compact and flat cables, made for instance of $\mathrm{Nb}-\mathrm{Ti} / \mathrm{Cu}$, $22 \mathrm{Nb}_{3} \mathrm{Sn} / \mathrm{Cu}$ strands, is that lap splices with a well-defined resis23 tance can be relatively easily produced by soft soldering. As 24 an example, the resistance of each of the about 10000 main 25 busbar cable splices of the Large Hadron Collider (LHC) [1] 26 at $1.9 \mathrm{~K}$ in self-field (about 0.7 Tesla at maximum current) is $270.30 \mathrm{n} \Omega$ [2].

28 The LHC busbar cables are surrounded by an additional $29 \mathrm{Cu}$ stabilizer [3]. The LHC interconnection splices consist 30 therefore of the Rutherford cable splices and the splices of the 31 stabilizer profiles (see Fig. 1). During the first long LHC shut32 down the resistance of all of the about 20000 LHC Cu stabilizer 33 profile splices has been measured at ambient temperature and 34 the results are reported elsewhere [4].

35 The goal of this paper is to describe how the resistance of 36 the superconducting Rutherford cable lap splices varies with 37 the intercable contact area and with different cable defects. In 38 addition we compare the resistance of the standard lap splices 39 to that of another splice geometry connecting two side-by-side 40 cables, as it could possibly happen to connect an inner and an 41 outer layer inside a magnet.

42 Splice resistances have been measured in self-field at $4.3 \mathrm{~K}$ 43 with two independent methods, notably by measuring the cur44 rent decay time in test loops with known inductance, and

Manuscript received August 6, 2014; accepted September 19, 2014

The authors are with the European Organization for Nuclear Research (CERN), 1211 Geneva 23, Switzerland (e-mail: Christian.Scheuerlein@ cern.ch).

Color versions of one or more of the figures in this paper are available online at http://ieeexplore.ieee.org.

Digital Object Identifier 10.1109/TASC.2014.2360296

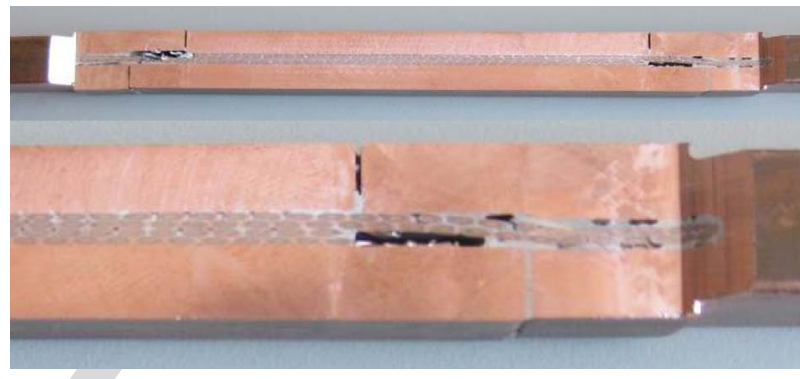

Fig. 1. Longitudinal cross section through an LHC main interconnection splice.

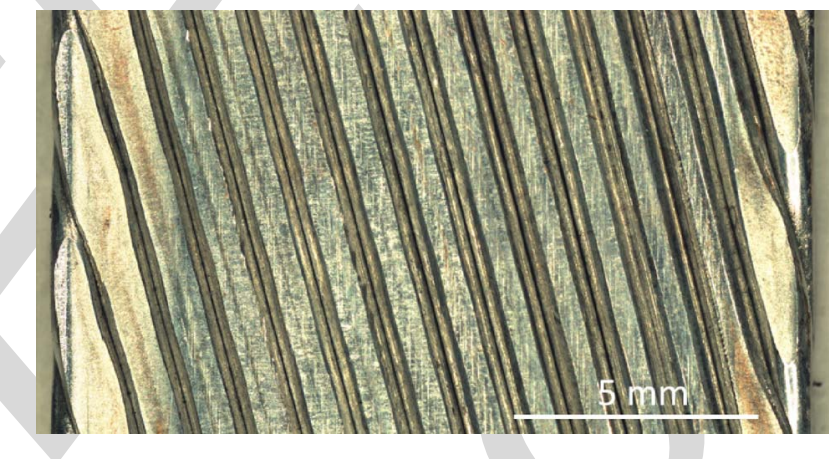

Fig. 2. Outer surface of an LHC-type 01 Rutherford cable.

by four-point resistance measurements with currents up to 45 $27000 \mathrm{~A}$.

II. EXPERIMENTAL

A. Rutherford Cable Splices

Splices made out of $\mathrm{Nb}-\mathrm{Ti} / \mathrm{Cu}$ LHC main busbar cable have 49 been assembled by soft soldering, using inductive heaters [5]. 50 The LHC superconducting strands are already coated with a 51 0.1 to $1 \mu \mathrm{m}$ thin $\mathrm{Sn}-\mathrm{Ag}$ layer [6]. In order to prevent the com- 52 plete transformation into $\mathrm{Cu}_{6} \mathrm{Sn}_{5}$ and $\mathrm{Cu}_{3} \mathrm{Sn}$ intermetallics [7], 53 before connection the cable extremities have been pre-tinned 54 in a resistively heated furnace. Soldering was performed using 55 $0.2 \mathrm{~mm}$ thick $\mathrm{Sn} 96 \mathrm{Ag} 4$ foil and non-activated rosin liquid 56 flux Kester 135. During the soldering process with a peak 57 temperature of $270{ }^{\circ} \mathrm{C}$ the residual resistivity ratio of the $\mathrm{Cu} 58$ matrix of the strands increases to about 200 [8].

The $15.1 \mathrm{~mm}$ wide LHC busbar cables consist of 36 strands 60 with a nominal diameter of $0.825 \mathrm{~mm}$. The cable mid-thickness 61 is $1.48 \mathrm{~mm}$ and the keystone angle is $0.90 \pm 0.05^{\circ}$. The cable 62 transposition pitch is $100 \pm 5 \mathrm{~mm}$ [9].

Fig. 2 shows the outer cable surface of an inner layer LHC 64 dipole conductor. It can be seen that the initially round strands 65 


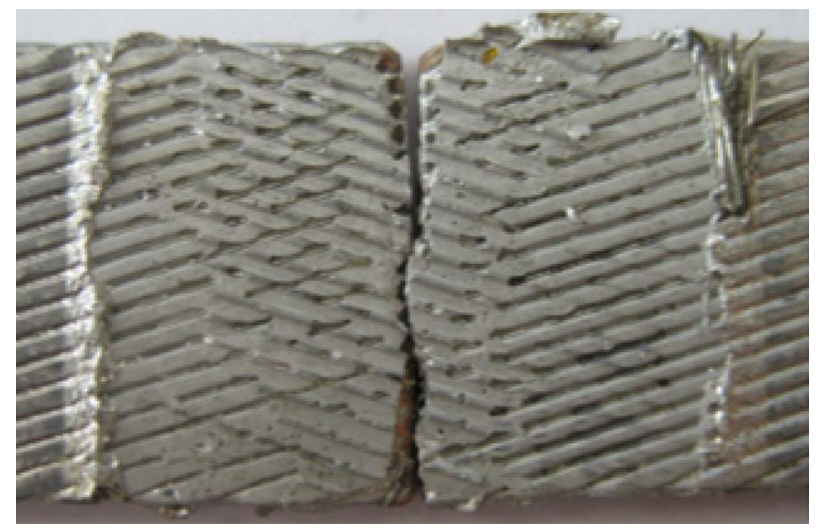

Fig. 3. Both intercable contact areas after fracturing of an LHC busbar cable splice with $10 \mathrm{~mm}$ cable overlap length.

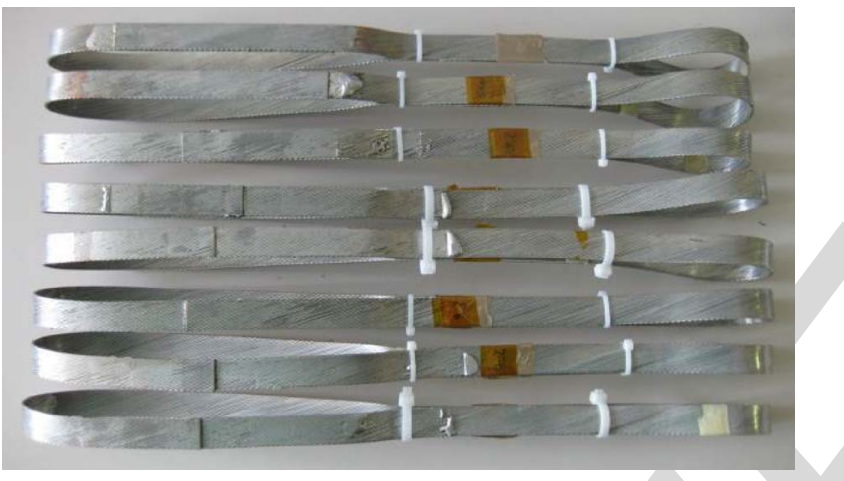

Fig. 4. LHC busbar cable test loops for current decay constant measurements. The cable splices have been prepared with different cable overlap lengths ranging from 3 to $120 \mathrm{~mm}$.

66 are flattened during the cabling process, and that the cable cross 67 section that is in contact with the opposing cable is significantly 68 smaller than the projected cable area and depends on the strand 69 diameter and the cable compaction.

70 The resistance of splices with cable overlap lengths varying 71 between 3 and $120 \mathrm{~mm}$ has been measured. The overlap lengths 72 have been measured after fracturing the splices during tensile 73 tests at $4.3 \mathrm{~K}$ (see Fig. 3). The accuracy of the stated cable 74 overlap lengths is $\pm 1 \mathrm{~mm}$.

\section{B. Resistance Measurements}

76 Splice resistance measurements have been performed with 77 two different methods, notably by measuring the current decay 78 time in test loops, and by four-point resistance measurements.

79 Current decay measurements have been performed at the 80 CERN Cryolab. The measurement of the current decay time 81 in test loops with a well defined geometry [10] allows to 82 determine very low splice resistances, which are difficult to 83 determine otherwise. Some of the test loops made of the spliced 84 Rutherford cables produced for this study are shown in Fig. 4. 85 The resistance $\mathrm{R}$ is determined from the loop inductance $\mathrm{L}$ 86 and the current decay time constant $\tau(\mathrm{R}=\mathrm{L} / \tau)$. The induc87 tance of $260 \mathrm{nH}$ that has been calculated for a busbar cable 88 loop with ideal dimension [11] is somewhat lower than the 89 average loop inductance of $306 \mathrm{nH}$ determined by comparing 90 splice resistance results obtained by four-point measurements

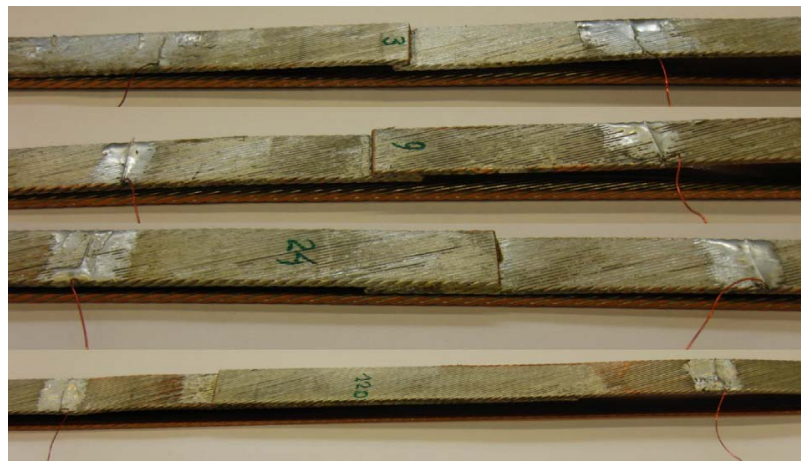

Fig. 5. Cable splices with 3, 9, 24, and $120 \mathrm{~mm}$ intercable contact lengths instrumented with voltage taps.

TABLE I

Current Decay Constant $\tau$ of 13 kA LHC Busbar Cable Splices With DifFERENT INTERCABLE CONTACT LENGTHS AT $4.3 \mathrm{~K}$

\begin{tabular}{llr}
\hline splice length $(\mathrm{mm})$ & $\tau(\mathrm{s})$ & $* \mathrm{R}(\mathrm{n} \Omega)$ \\
\hline 120 & $970 \pm 42$ & 0.31 \\
24 & $158 \pm 3.8$ & 1.93 \\
9.7 & $64.4 \pm 10$ & 4.75 \\
3.6 & $29.7 \pm 2.4$ & 10.3 \\
\hline * The splice resistance $\mathrm{R}$ is calculated from $\tau$, assuming
\end{tabular}

and the decay constants for the loops made with the same 91 splices. The experimentally determined value of $306 \mathrm{nH}$ is used 92 in the following.

Four-point resistance measurements in self-field at $4.3 \mathrm{~K} 94$ have been performed in the FRESCA test station [12]. Several 95 splices are connected in series. The distance between the differ- 96 ent splices is about $120 \mathrm{~mm}$. The voltage taps are placed in a 97 distance of $50 \mathrm{~mm}$ from each splice extremity. Photographs of 98 the splices with 3, 9, 24, and $120 \mathrm{~mm}$ overlap lengths that were 99 used for the four-point measurements are shown in Fig. 5.

\section{RESULTS}

A. Splice Resistance as a Function of Cable Overlap Length

102

Since the resistance in the superconductor along the con- 103 tinuous $\mathrm{Nb}$-Ti filaments is zero, it can be assumed that the 104 cable splice resistance is inversely proportional to the intercable 105 contact area. In order to confirm this assumption resistance 106 measurements have been performed with LHC busbar lap 107 splices for which the overlap length has been varied between 108 $3 \mathrm{~mm}$ and the nominal splice length of $120 \mathrm{~mm}$.

The current decay constants determined with loops with lap 110 splices (see Fig. 4) are summarized in Table I. The results 111 shown are average values for three loops that have been pro- 112 duced for each nominal overlap length.

After the current decay constant measurements the loops 114 were cut (see Fig. 5) so that the four-point splice resistance 115 measurements could be performed. The voltages measured 116 across the different splices at $4.3 \mathrm{~K}$ as a function of the test 117 current up to $15 \mathrm{kA}$ are presented in Fig. 6. Each data point has 118 been averaged over a measurement time of $300 \mathrm{sec}$. The current 119 


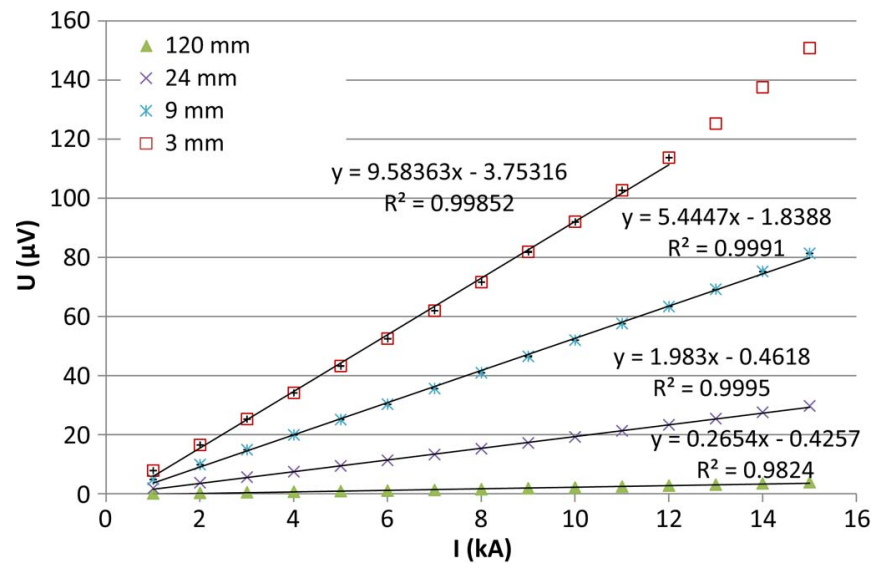

Fig. 6. Electrical potential $\mathrm{U}$ as a function of current $\mathrm{I}$ at $4.3 \mathrm{~K}$ without external field for splices with 3,9, 24, and $120 \mathrm{~mm}$ intercable contact lengths.

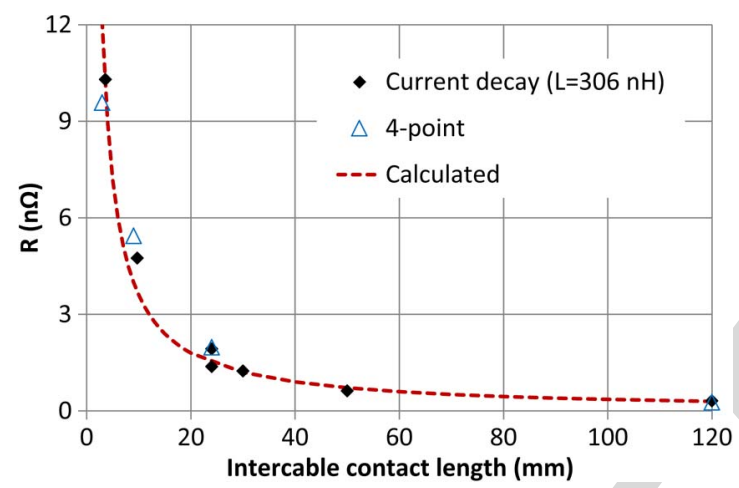

Fig. 7. Comparison of the measured and calculated LHC busbar cable splice resistances as a function of intercable overlap length.

120 ramp was about $300 \mathrm{~A} / \mathrm{s}$. Voltages below $2 \mu \mathrm{V}$ have not been 121 taken into account for the resistance calculations.

122 The $4.3 \mathrm{~K}$ resistances vary between $0.27 \mathrm{n} \Omega(1200 \mathrm{~mm}$ 123 overlap) and $9.6 \mathrm{n} \Omega(3 \mathrm{~mm}$ overlap). For the $3 \mathrm{~mm}$ splice the 124 data points above $12 \mathrm{kA}$ have not been considered because they 125 appear to deviate from the linear voltage-current relationship, 126 possibly because the critical current in some or all strands is 127 approached (the quench current of the $3 \mathrm{~mm}$ splice was about $12817 \mathrm{kA})$.

129 In Fig. 7 the resistances measured for splices with different 130 overlap length are compared with resistances that were calcu131 lated assuming that the splice resistance is inversely propor132 tional to the contact length, and that a splice with $120 \mathrm{~mm}$ 133 overlap length has a resistance of $0.30 \mathrm{n} \Omega$, which is the average 134 LHC busbar splice resistance measured in situ in the LHC [2]. 135 It can be seen that in the contact length range 3-120 $\mathrm{mm}$ the 136 splice resistance can be well predicted when the resistance of 137 one splice overlap length is known.

\section{B. Side-by-Side Cable Bridge Splice}

139 The production of lap splices always requires some cable 140 movement and bending, which is acceptable in case of ductile $141 \mathrm{Nb}-\mathrm{Ti} / \mathrm{Cu}$ cables, but may be a problem for brittle cables, like $142 \mathrm{Nb}_{3} \mathrm{Sn} / \mathrm{Cu}$. A bridge splice can connect two side-by-side cables 143 without any cable bending. In order to verify if the resistance of

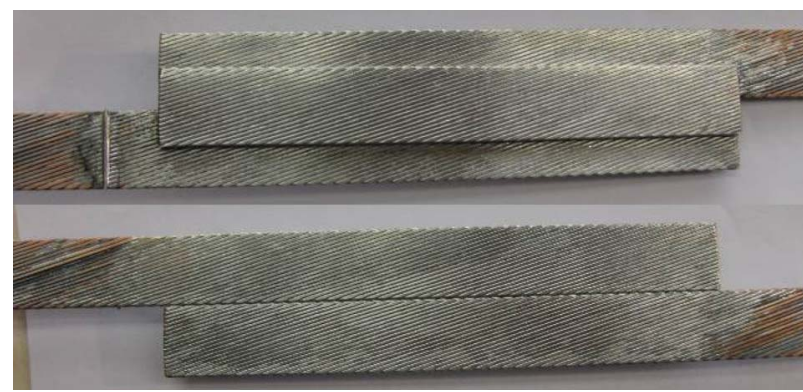

Fig. 8. Splice with two side-by-side cables connected with one opposing cable.

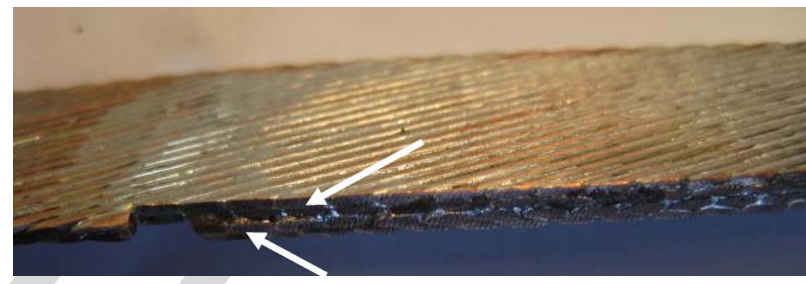

Fig. 9. Rutherford cable splice made with cables in which the strands of both opposing cables were cut on one side along the entire $120 \mathrm{~mm}$ overlap length.

such a bridge can be predicted with the simple assumption that 144 the resistance is inversely proportional to the intercable contact 145 area we have produced and tested the bridge splice shown in 146 Fig. 8. The resistance of this splice is $1.31 \mathrm{n} \Omega$.

147

The bridge splice can be considered as two lap splices that 148 are connected in series. The intercable contact area of each of 149 these is about half of that of a standard LHC lap splice. With 150 this assumption a total resistance of two times $0.6 \mathrm{n} \Omega=1.2 \mathrm{n} \Omega 151$ can be calculated, which is in reasonable agreement with the 152 measured resistance of $1.31 \mathrm{n} \Omega$.

\section{Influence of Mechanical Defects on the Resistance of} 120 mm Overlap Lap Splices

In order to determine the influence of different geometrical 156 cable defects on the splice resistance, lap splices with $120 \mathrm{~mm} 157$ overlap length have been prepared using LHC busbar cable on 158 which part of the strands had been cut. Fig. 9 shows a splice 159 made of two cables with all strands cut on one side along the 160 entire $120 \mathrm{~mm}$ intercable contact length.

As shown in Fig. 10 this defect increases the splice resistance 162 to $0.45 \mathrm{n} \Omega$, which is about $50 \%$ higher than the resistance of 163 a defect free splice. A relatively strong resistance increase to 164 $2.7 \mathrm{n} \Omega$ is obtained when all strands are cut along both cables on 165 both sides of the splice.

166

The $120 \mathrm{~mm}$ splice resistances are summarized in Table II. 167

\section{Discussion AND CONCLUSION}

In the following discussion it is assumed that the influence 169 of the solder resistance on the overall splice resistance can 170 be neglected. This assumption is based on the resistivity re- 171 sults obtained for the solder material [13], and on resistance 172 measurements of splices soldered with different solder alloys 173 [14]. The resistance of $\mathrm{Nb}-\mathrm{Ti} / \mathrm{Cu}$ Rutherford-type cables lap 174 


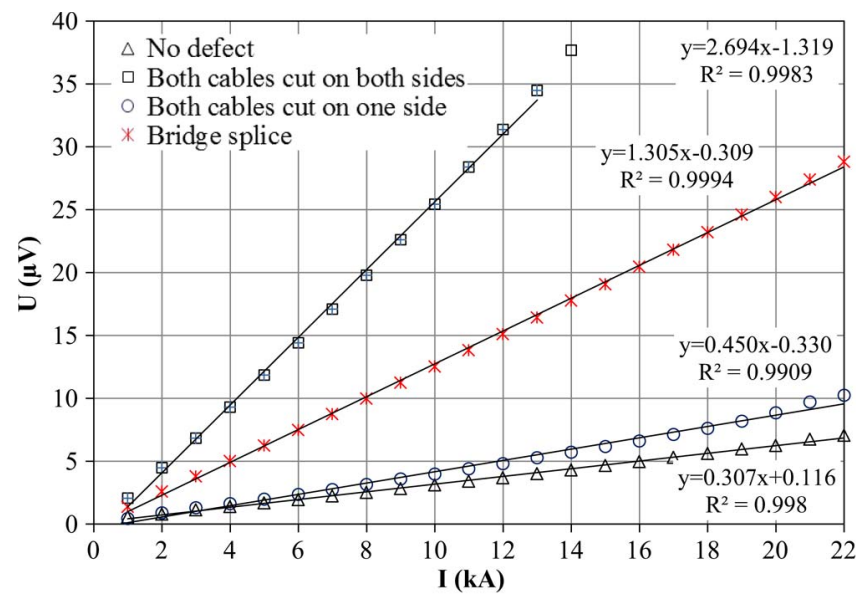

Fig. 10. Electrical potential $\mathrm{U}$ as a function of current $\mathrm{I}$ at $4.3 \mathrm{~K}$ without external field for splices with $120 \mathrm{~mm}$ intercable contact length and different defects. The results for the bridge splice of Fig. 8 is shown as well.

TABLE II

Resistance of 120 mm Long 13 kA LHC Busbar Cable Splices With DifFERENT DefeCts AT 4.3 K IN SELF-Field

\begin{tabular}{lcc}
\hline \multicolumn{1}{c}{ Defect } & $\mathrm{R}_{\text {loop }}(\mathrm{n} \Omega)^{*}$ & $\mathrm{R}_{\text {4-point }}(\mathrm{n} \Omega)$ \\
\hline $\begin{array}{l}\text { None } \\
\text { Bridge splice }\end{array}$ & $0.26 \pm 0.03$ & 0.31 \\
$\begin{array}{l}\text { All strands of both } \\
\text { cables cut on one side }\end{array}$ & $0.48 \pm 0.07$ & 1.31 \\
$\begin{array}{l}\text { All strands of both } \\
\text { cables cut on both sides }\end{array}$ & n.m. & 0.45 \\
\hline
\end{tabular}

* Assumming a loop inductance of $306 \mathrm{nH}$.

175 splices can then be predicted from the $\mathrm{Cu}$ cross sections and the $176 \mathrm{Cu}$ RRR involved. This is also the case for Rutherford cables 177 made of $\mathrm{Nb}_{3} \mathrm{Sn} / \mathrm{Cu}$ wires, provided that diffusion barriers do 178 not strongly contribute to the splice resistance [13].

179 Since the resistance along the superconducting filaments of 180 the continuous cable is zero it can be assumed that in longitu181 dinal cable direction the current is uniformly distributed over 182 the entire splice length, and the splice resistance is inversely 183 proportional to the intercable contact length. This is confirmed 184 by the resistance results obtained for the Rutherford cable lap 185 splices produced with different overlap lengths (see Fig. 7).

186 The influence of single cut strands on the resistance of the 187 LHC busbar cable splices is negligible. The extreme case where 188 all strands are cut on both sides of the Rutherford cables along 189 the entire splice length causes a resistance of about $2.7 \mathrm{n} \Omega$.

190 The resistance results presented here have been obtained in 191 self-field with a huge critical current density margin of the $192 \mathrm{Nb}-\mathrm{Ti}$ superconductor. The application of external fields influ193 ences the resistance of internal magnet splices because of the 194 additional $\mathrm{Cu}$ magnetoresistance, and in case the critical current 195 density is exceeded in some strands by a current redistribution. 196 The resistance of a bridge splice can be estimated from the 197 resistance of a lap splice produced with the same cable, and 198 the intercable contact areas. Unlike lap splices, bridge splices 199 allow to interconnect cables without any cable bending, which 200 is important when brittle superconductors need to be connected.
With a bridge splice a layer jump inside a $\mathrm{Nb}_{3} \mathrm{Sn}$ magnet 201 maybe possible. Further studies are needed to understand the 202 performance of the different splice layouts in high applied 203 fields.

Because of the strong field dependence of the critical current 205 density of $\mathrm{Nb}-\mathrm{Ti}$ and $\mathrm{Nb}_{3} \mathrm{Sn}$ superconductors, there is always a 206 huge margin in terms of critical current density for splices that 207 are outside the high field region of a magnet. The critical current 208 density of high temperature superconductors like Bi-2212 is 209 only relatively weakly related to the applied field, and if such 210 conductors are exploited at their full potential the $I_{c}$ margin 211 in self-field will be relatively small, so that the splice pro- 212 duction and non-destructive splice tests will require particular 213 attention.

\section{ACKNOWLEDGMENT}

We are grateful to M. Pozobon and O. Kalouguine for the 216 production of the splices and to S. Prunet from the CERN 217 Cryolab for the current decay constant measurements.

\section{REFERENCES}

[1] L. Evans, Ed., The Large Hadron Collider: A Marvel of Technology. 220 Boca Raton, FL, USA: CRC Press, 2009.

[2] Z. Charifoulline, K. Dahlerup-Petersen, R. Denz, A. Siemko, and 222 J. Steckert, "Splice resistance measurements in the LHC main 223 superconducting magnet circuits by the new quench protection system," 224 in Proc. IPAC, New Orleans, LA, USA, 2012, pp. 3557-3559. 225

[3] L. Belova, M. Genet, J.-L. Perinet-Marquet, P. Ivanov, and C. Urpin, 226 "Design and manufacture of the superconducting bus-bars for the LHC 227 main magnets," IEEE Trans. Appl. Supercond., vol. 12, no. 1, pp. 1305- 228 1309, Mar. 2002.

[4] S. Heck et al., "Non-destructive testing and quality control of the 230 LHC main interconnection splices," IEEE Trans. Appl. Supercond., to be 231 published.

[5] A. Jacquemod, A. Poncet, F. Schauf, B. Skoczen, and J. P. Tock, "Induc- 233 tive soldering of the junctions of the main superconducting busbars of 234 the LHC," CERN, Geneva, Switzerland, Sep. 4, 2003.

[6] C. Scheuerlein, G. Arnau, N. Charras, L. Oberli, and M. Taborelli, 236 "The thickness measurement of $\mathrm{Sn}-\mathrm{Ag}$ coatings on LHC supercon- 237 ducting strands by coulometry," J. Electrochem. Soc., vol. 151, no. 6, 238 pp. 206-212, 2004.

[7] C. Scheuerlein et al. "The effect of CuSn intermetallics on the 240 interstrand contact resistance in LHC superconducting cables," J. Appl. 241 Phys., vol. 97, no. 3, Feb. 2005, Art. ID. 033909.

[8] S. Heck, C. Scheuerlein, P. Fessia, and R. Principe, "The RRR of the 243 Cu components of the LHC main busbar splices," CERN TE-MSC, 244 Geneva, Switzerland, 2010, Tech. Note EDMS Nr. 1057918.

[9] LHC Cable Characteristics.

[10] R. Herzog and D. Hagedorn, "Inductive method to measure very small 247 joint resistances of superconducting wires," Div. LHC, CERN, Geneva, 248 Switzerland.

[11] S. Heck et al., "Electrical resistance and mechanical strength of LHC 250 busbar cable splices as a function of intercable contact length," CERN, 251 Geneva, Switzerland, CERN-ATS-Note-2011-074, 2011, EDMS Nr. 252 1159508.

[12] A. P. Verweij et al., " $1.9 \mathrm{~K}$ test facility for the reception of the supercon- 254 ducting cables for the LHC," CERN, Geneva, Switzerland, LHC Project 255 Rep. 246, Oct. 1998.

[13] D. Schoerling, S. Heck, C. Scheuerlein, S. Atieh, and R. Schaefer, "Elec- 257 trical resistance of $\mathrm{Nb}_{3} \mathrm{Sn} / \mathrm{Cu}$ splices produced by electromagnetic pulse 258 technology and soft soldering," Supercond. Sci. Technol., vol. 25, no. 2, 259 Feb. 2012, Art. ID. 025006

[14] R. Lutum, S. Heck, and C. Scheuerlein, "Electrical resistance of the 261 solder connections for the consolidation of the LHC main interconnec- 262 tion splices," IEEE Trans. Appl. Supercond., vol. 23, no. 3, Jun. 2013, 263 Art. ID. 3800404 


\section{AUTHOR QUERIES}

\section{AUTHOR PLEASE ANSWER ALL QUERIES}

AQ1 = Please provide publication update in Ref. [4]

AQ2 = Please provide publication update in Ref. [9].

END OF ALL QUERIES 


\title{
The Electrical Resistance of Rutherford-Type Superconducting Cable Splices

\author{
S. Heck, C. Scheuerlein, J. Fleiter, A. Ballarino, and L. Bottura
}

\begin{abstract}
4 Abstract-The electrical resistance of Large Hadron Collider 5 main busbar cable lap splices produced by soft soldering has 6 been measured with two independent methods as a function of 7 intercable contact area and for splices made of cables with various 8 defects. For defect-free lap splices, the resistance increases from 90.3 to $10 \mathrm{n} \Omega$ (at $4.3 \mathrm{~K}$ in self-field) when reducing the cable 10 overlap length from 120 to $3 \mathrm{~mm}$, as expected assuming that the 11 resistance is inversely proportional to the intercable contact area. 12 The resistance of bridge splices that connect side-by-side cables 13 can be predicted from the lap splice resistances and the overlap 14 areas involved.
\end{abstract}

15 Index Terms-Cables, inductance, interconnection, resistance 16 measurement.

\section{INTRODUCTION}

18

, $\mathbf{R}$ UTHERFORD-TYPE cables are widely used for building accelerator magnet coils when the inductance of a magnet 20 wound of a single wire would be too high. An advantage of 21 these compact and flat cables, made for instance of $\mathrm{Nb}-\mathrm{Ti} / \mathrm{Cu}$, $22 \mathrm{Nb}_{3} \mathrm{Sn} / \mathrm{Cu}$ strands, is that lap splices with a well-defined resis23 tance can be relatively easily produced by soft soldering. As 24 an example, the resistance of each of the about 10000 main 25 busbar cable splices of the Large Hadron Collider (LHC) [1] 26 at $1.9 \mathrm{~K}$ in self-field (about 0.7 Tesla at maximum current) is $270.30 \mathrm{n} \Omega$ [2].

28 The LHC busbar cables are surrounded by an additional $29 \mathrm{Cu}$ stabilizer [3]. The LHC interconnection splices consist 30 therefore of the Rutherford cable splices and the splices of the 31 stabilizer profiles (see Fig. 1). During the first long LHC shut32 down the resistance of all of the about $20000 \mathrm{LHC} \mathrm{Cu}$ stabilizer 33 profile splices has been measured at ambient temperature and 34 the results are reported elsewhere [4].

35 The goal of this paper is to describe how the resistance of 36 the superconducting Rutherford cable lap splices varies with 37 the intercable contact area and with different cable defects. In 38 addition we compare the resistance of the standard lap splices 39 to that of another splice geometry connecting two side-by-side 40 cables, as it could possibly happen to connect an inner and an 41 outer layer inside a magnet.

42 Splice resistances have been measured in self-field at $4.3 \mathrm{~K}$ 43 with two independent methods, notably by measuring the cur44 rent decay time in test loops with known inductance, and

Manuscript received August 6, 2014; accepted September 19, 2014

The authors are with the European Organization for Nuclear Research (CERN), 1211 Geneva 23, Switzerland (e-mail: Christian.Scheuerlein@ cern.ch).

Color versions of one or more of the figures in this paper are available online at http://ieeexplore.iee.org.

Digital Object Identifier 10.1109/TASC.2014.2360296

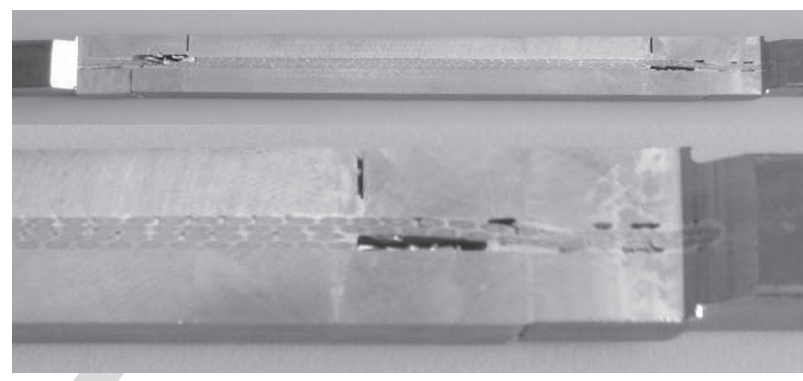

Fig. 1. Longitudinal cross section through an LHC main interconnection splice.

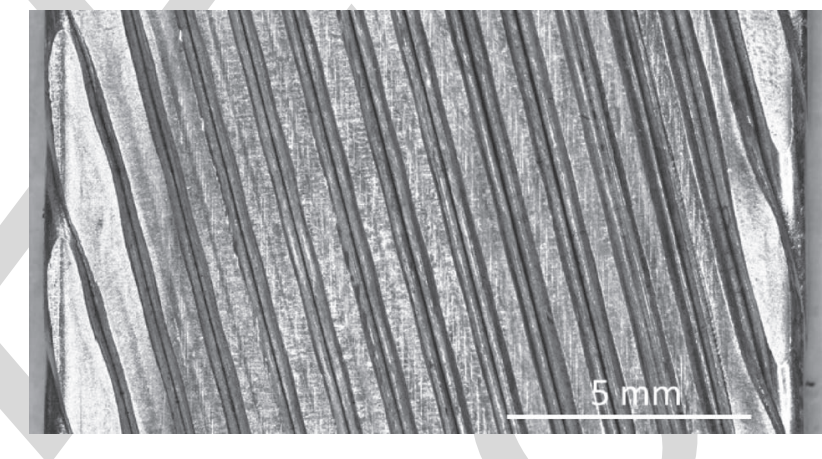

Fig. 2. Outer surface of an LHC-type 01 Rutherford cable.

by four-point resistance measurements with currents up to 45 $27000 \mathrm{~A}$.

II. EXPERIMENTAL

A. Rutherford Cable Splices

Splices made out of $\mathrm{Nb}-\mathrm{Ti} / \mathrm{Cu}$ LHC main busbar cable have 49 been assembled by soft soldering, using inductive heaters [5]. 50 The LHC superconducting strands are already coated with a 51 0.1 to $1 \mu \mathrm{m}$ thin $\mathrm{Sn}-\mathrm{Ag}$ layer [6]. In order to prevent the com- 52 plete transformation into $\mathrm{Cu}_{6} \mathrm{Sn}_{5}$ and $\mathrm{Cu}_{3} \mathrm{Sn}$ intermetallics [7], 53 before connection the cable extremities have been pre-tinned 54 in a resistively heated furnace. Soldering was performed using 55 $0.2 \mathrm{~mm}$ thick $\mathrm{Sn} 96 \mathrm{Ag} 4$ foil and non-activated rosin liquid 56 flux Kester 135. During the soldering process with a peak 57 temperature of $270{ }^{\circ} \mathrm{C}$ the residual resistivity ratio of the $\mathrm{Cu} 58$ matrix of the strands increases to about 200 [8].

The $15.1 \mathrm{~mm}$ wide LHC busbar cables consist of 36 strands 60 with a nominal diameter of $0.825 \mathrm{~mm}$. The cable mid-thickness 61 is $1.48 \mathrm{~mm}$ and the keystone angle is $0.90 \pm 0.05^{\circ}$. The cable 62 transposition pitch is $100 \pm 5 \mathrm{~mm}$ [9].

Fig. 2 shows the outer cable surface of an inner layer LHC 64 dipole conductor. It can be seen that the initially round strands 65 


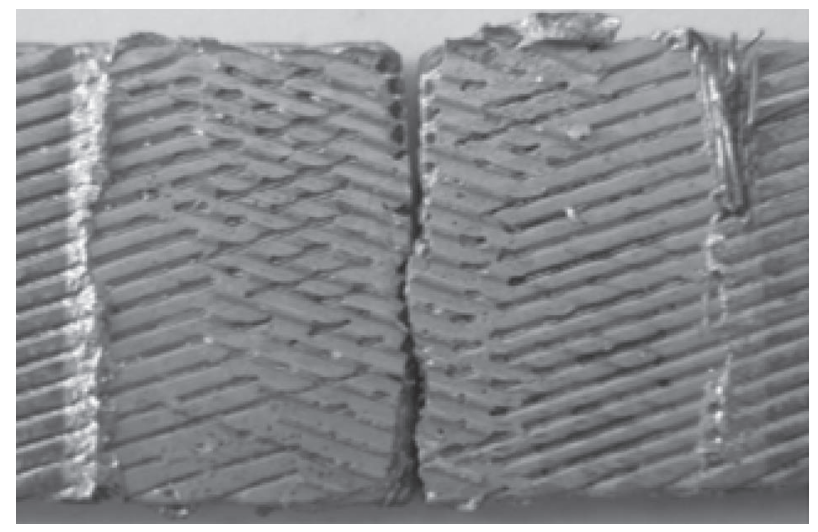

Fig. 3. Both intercable contact areas after fracturing of an LHC busbar cable splice with $10 \mathrm{~mm}$ cable overlap length.

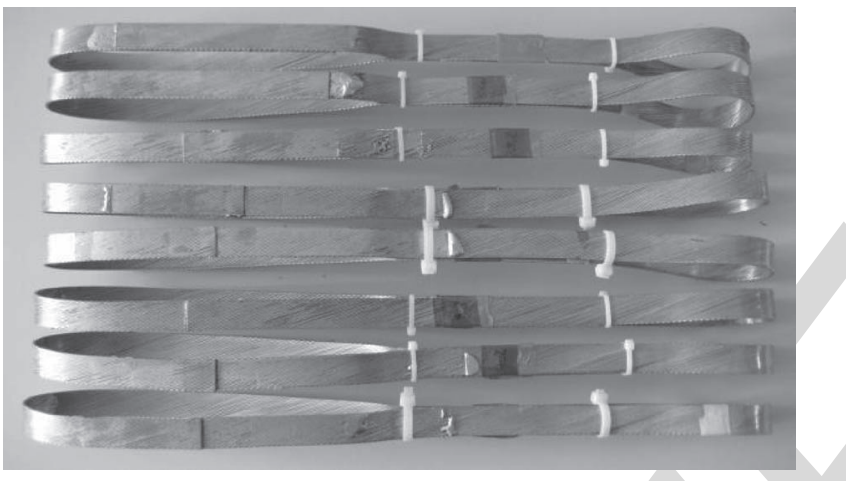

Fig. 4. LHC busbar cable test loops for current decay constant measurements. The cable splices have been prepared with different cable overlap lengths ranging from 3 to $120 \mathrm{~mm}$.

66 are flattened during the cabling process, and that the cable cross 67 section that is in contact with the opposing cable is significantly 68 smaller than the projected cable area and depends on the strand 69 diameter and the cable compaction.

70 The resistance of splices with cable overlap lengths varying 71 between 3 and $120 \mathrm{~mm}$ has been measured. The overlap lengths 72 have been measured after fracturing the splices during tensile 73 tests at $4.3 \mathrm{~K}$ (see Fig. 3). The accuracy of the stated cable 74 overlap lengths is $\pm 1 \mathrm{~mm}$.

\section{B. Resistance Measurements}

76 Splice resistance measurements have been performed with 77 two different methods, notably by measuring the current decay 78 time in test loops, and by four-point resistance measurements.

79 Current decay measurements have been performed at the 80 CERN Cryolab. The measurement of the current decay time 81 in test loops with a well defined geometry [10] allows to 82 determine very low splice resistances, which are difficult to 83 determine otherwise. Some of the test loops made of the spliced 84 Rutherford cables produced for this study are shown in Fig. 4. 85 The resistance $\mathrm{R}$ is determined from the loop inductance $\mathrm{L}$ 86 and the current decay time constant $\tau(\mathrm{R}=\mathrm{L} / \tau)$. The induc87 tance of $260 \mathrm{nH}$ that has been calculated for a busbar cable 88 loop with ideal dimension [11] is somewhat lower than the 89 average loop inductance of $306 \mathrm{nH}$ determined by comparing 90 splice resistance results obtained by four-point measurements

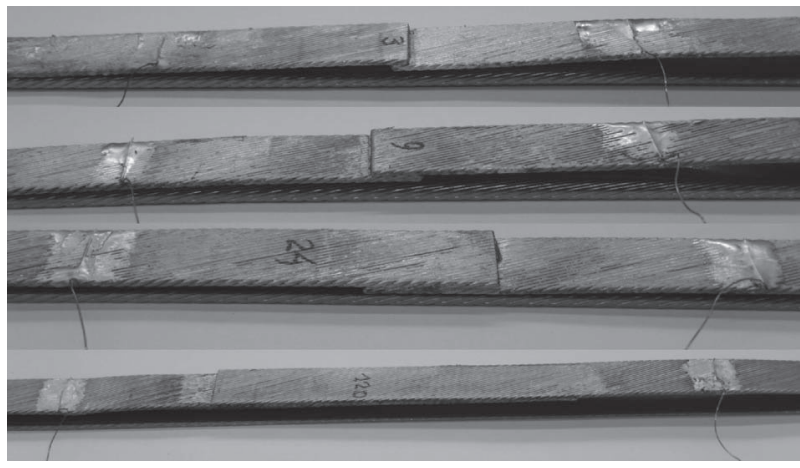

Fig. 5. Cable splices with 3, 9, 24, and $120 \mathrm{~mm}$ intercable contact lengths instrumented with voltage taps.

TABLE I

Current Decay Constant $\tau$ of 13 kA LHC Busbar Cable Splices With Different Intercable ContaCt Lengths AT $4.3 \mathrm{~K}$

\begin{tabular}{llr}
\hline splice length $(\mathrm{mm})$ & $\tau(\mathrm{s})$ & $* \mathrm{R}(\mathrm{n} \Omega)$ \\
\hline 120 & $970 \pm 42$ & 0.31 \\
24 & $158 \pm 3.8$ & 1.93 \\
9.7 & $64.4 \pm 10$ & 4.75 \\
3.6 & $29.7 \pm 2.4$ & 10.3 \\
\hline * The splice resistance $\mathrm{R}$ is calculated from $\tau$, assuming
\end{tabular}
a loop inductance of $306 \mathrm{nH}$.

and the decay constants for the loops made with the same 91 splices. The experimentally determined value of $306 \mathrm{nH}$ is used 92 in the following.

Four-point resistance measurements in self-field at $4.3 \mathrm{~K} 94$ have been performed in the FRESCA test station [12]. Several 95 splices are connected in series. The distance between the differ- 96 ent splices is about $120 \mathrm{~mm}$. The voltage taps are placed in a 97 distance of $50 \mathrm{~mm}$ from each splice extremity. Photographs of 98 the splices with 3, 9, 24, and $120 \mathrm{~mm}$ overlap lengths that were 99 used for the four-point measurements are shown in Fig. 5.

\section{RESULTS}

A. Splice Resistance as a Function of Cable Overlap Length

102

Since the resistance in the superconductor along the con- 103 tinuous $\mathrm{Nb}$-Ti filaments is zero, it can be assumed that the 104 cable splice resistance is inversely proportional to the intercable 105 contact area. In order to confirm this assumption resistance 106 measurements have been performed with LHC busbar lap 107 splices for which the overlap length has been varied between 108 $3 \mathrm{~mm}$ and the nominal splice length of $120 \mathrm{~mm}$.

The current decay constants determined with loops with lap 110 splices (see Fig. 4) are summarized in Table I. The results 111 shown are average values for three loops that have been pro- 112 duced for each nominal overlap length.

After the current decay constant measurements the loops 114 were cut (see Fig. 5) so that the four-point splice resistance 115 measurements could be performed. The voltages measured 116 across the different splices at $4.3 \mathrm{~K}$ as a function of the test 117 current up to $15 \mathrm{kA}$ are presented in Fig. 6. Each data point has 118 been averaged over a measurement time of $300 \mathrm{sec}$. The current 119 


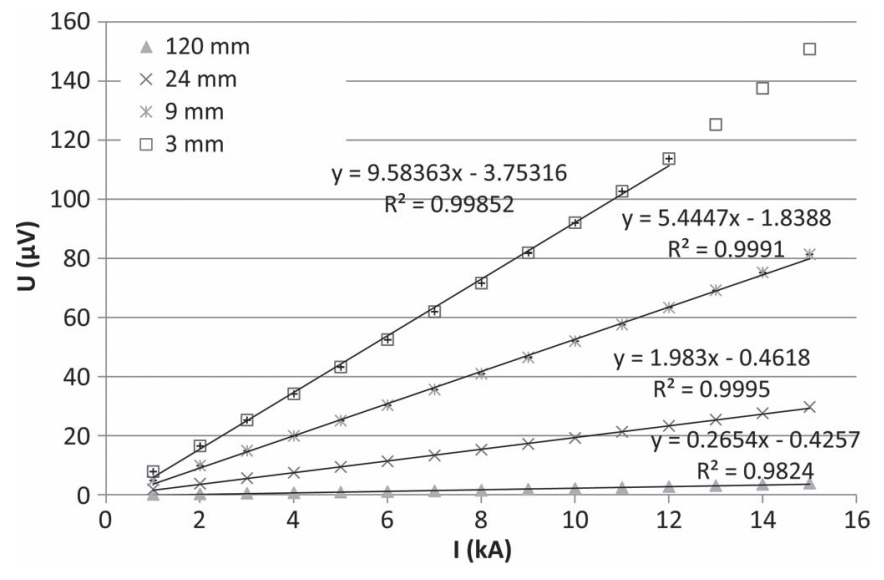

Fig. 6. Electrical potential $\mathrm{U}$ as a function of current $\mathrm{I}$ at $4.3 \mathrm{~K}$ without external field for splices with 3,9, 24, and $120 \mathrm{~mm}$ intercable contact lengths.

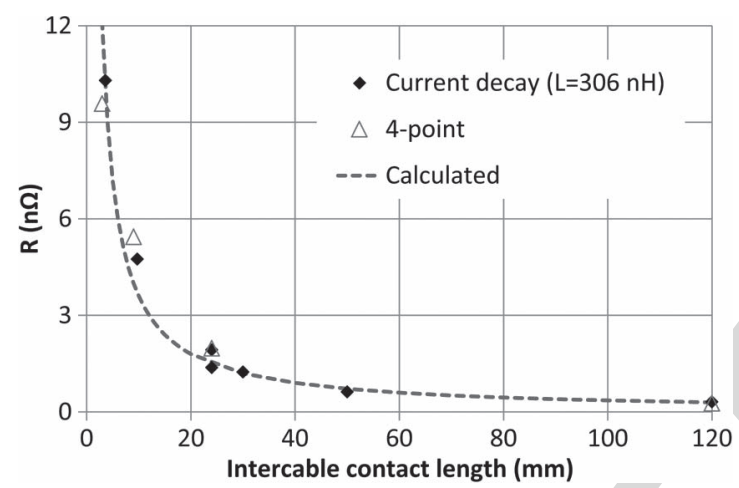

Fig. 7. Comparison of the measured and calculated LHC busbar cable splice resistances as a function of intercable overlap length.

120 ramp was about $300 \mathrm{~A} / \mathrm{s}$. Voltages below $2 \mu \mathrm{V}$ have not been 121 taken into account for the resistance calculations.

122 The $4.3 \mathrm{~K}$ resistances vary between $0.27 \mathrm{n} \Omega(1200 \mathrm{~mm}$ 123 overlap) and $9.6 \mathrm{n} \Omega(3 \mathrm{~mm}$ overlap). For the $3 \mathrm{~mm}$ splice the 124 data points above $12 \mathrm{kA}$ have not been considered because they 125 appear to deviate from the linear voltage-current relationship, 126 possibly because the critical current in some or all strands is 127 approached (the quench current of the $3 \mathrm{~mm}$ splice was about $12817 \mathrm{kA})$.

129 In Fig. 7 the resistances measured for splices with different 130 overlap length are compared with resistances that were calcu131 lated assuming that the splice resistance is inversely propor132 tional to the contact length, and that a splice with $120 \mathrm{~mm}$ 133 overlap length has a resistance of $0.30 \mathrm{n} \Omega$, which is the average 134 LHC busbar splice resistance measured in situ in the LHC [2]. 135 It can be seen that in the contact length range 3-120 $\mathrm{mm}$ the 136 splice resistance can be well predicted when the resistance of 137 one splice overlap length is known.

\section{B. Side-by-Side Cable Bridge Splice}

139 The production of lap splices always requires some cable 140 movement and bending, which is acceptable in case of ductile $141 \mathrm{Nb}-\mathrm{Ti} / \mathrm{Cu}$ cables, but may be a problem for brittle cables, like $142 \mathrm{Nb}_{3} \mathrm{Sn} / \mathrm{Cu}$. A bridge splice can connect two side-by-side cables 143 without any cable bending. In order to verify if the resistance of

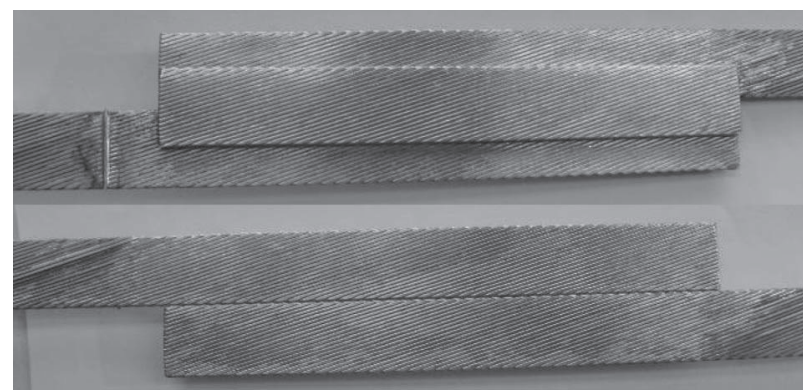

Fig. 8. Splice with two side-by-side cables connected with one opposing cable.

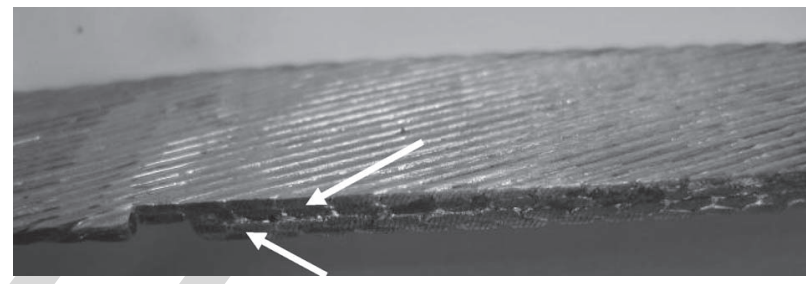

Fig. 9. Rutherford cable splice made with cables in which the strands of both opposing cables were cut on one side along the entire $120 \mathrm{~mm}$ overlap length.

such a bridge can be predicted with the simple assumption that 144 the resistance is inversely proportional to the intercable contact 145 area we have produced and tested the bridge splice shown in 146 Fig. 8. The resistance of this splice is $1.31 \mathrm{n} \Omega$.

147

The bridge splice can be considered as two lap splices that 148 are connected in series. The intercable contact area of each of 149 these is about half of that of a standard LHC lap splice. With 150 this assumption a total resistance of two times $0.6 \mathrm{n} \Omega=1.2 \mathrm{n} \Omega 151$ can be calculated, which is in reasonable agreement with the 152 measured resistance of $1.31 \mathrm{n} \Omega$.

\section{Influence of Mechanical Defects on the Resistance of} 120 mm Overlap Lap Splices

In order to determine the influence of different geometrical 156 cable defects on the splice resistance, lap splices with $120 \mathrm{~mm} 157$ overlap length have been prepared using LHC busbar cable on 158 which part of the strands had been cut. Fig. 9 shows a splice 159 made of two cables with all strands cut on one side along the 160 entire $120 \mathrm{~mm}$ intercable contact length.

As shown in Fig. 10 this defect increases the splice resistance 162 to $0.45 \mathrm{n} \Omega$, which is about $50 \%$ higher than the resistance of 163 a defect free splice. A relatively strong resistance increase to 164 $2.7 \mathrm{n} \Omega$ is obtained when all strands are cut along both cables on 165 both sides of the splice.

166

The $120 \mathrm{~mm}$ splice resistances are summarized in Table II. 167

\section{Discussion AND CONCLUSION}

In the following discussion it is assumed that the influence 169 of the solder resistance on the overall splice resistance can 170 be neglected. This assumption is based on the resistivity re- 171 sults obtained for the solder material [13], and on resistance 172 measurements of splices soldered with different solder alloys 173 [14]. The resistance of $\mathrm{Nb}-\mathrm{Ti} / \mathrm{Cu}$ Rutherford-type cables lap 174 


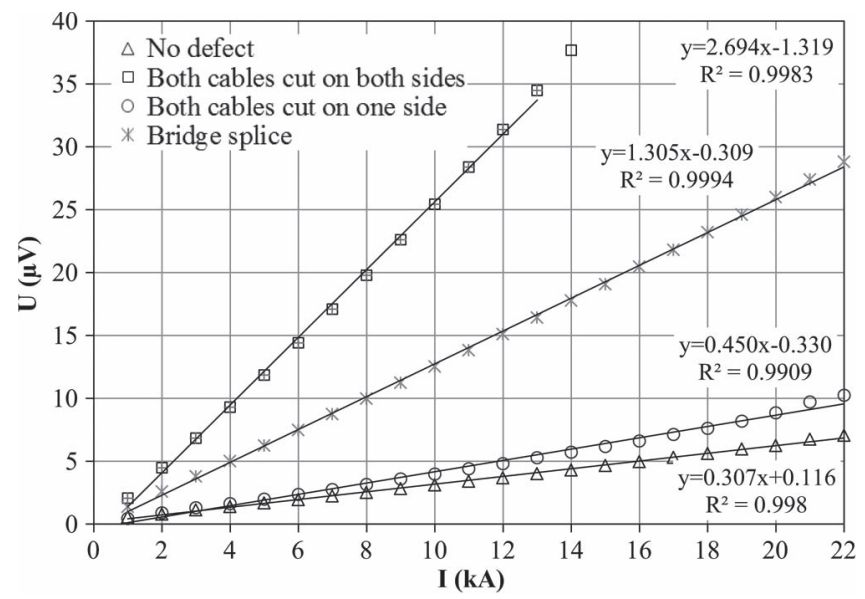

Fig. 10. Electrical potential $\mathrm{U}$ as a function of current $\mathrm{I}$ at $4.3 \mathrm{~K}$ without external field for splices with $120 \mathrm{~mm}$ intercable contact length and different defects. The results for the bridge splice of Fig. 8 is shown as well.

TABLE II

Resistance of 120 mm Long 13 kA LHC Busbar Cable Splices With DifFERENT DefeCts AT 4.3 K IN SELF-Field

\begin{tabular}{lcc}
\hline \multicolumn{1}{c}{ Defect } & $\mathrm{R}_{\text {loop }}(\mathrm{n} \Omega)^{*}$ & $\mathrm{R}_{\text {4-point }}(\mathrm{n} \Omega)$ \\
\hline $\begin{array}{l}\text { None } \\
\text { Bridge splice }\end{array}$ & $0.26 \pm 0.03$ & 0.31 \\
$\begin{array}{l}\text { All strands of both } \\
\text { cables cut on one side }\end{array}$ & $0.48 \pm 0.07$ & 1.31 \\
$\begin{array}{l}\text { All strands of both } \\
\text { cables cut on both sides }\end{array}$ & n.m. & 0.45 \\
\hline
\end{tabular}

* Assumming a loop inductance of $306 \mathrm{nH}$.

175 splices can then be predicted from the $\mathrm{Cu}$ cross sections and the $176 \mathrm{Cu}$ RRR involved. This is also the case for Rutherford cables 177 made of $\mathrm{Nb}_{3} \mathrm{Sn} / \mathrm{Cu}$ wires, provided that diffusion barriers do 178 not strongly contribute to the splice resistance [13].

179 Since the resistance along the superconducting filaments of 180 the continuous cable is zero it can be assumed that in longitu181 dinal cable direction the current is uniformly distributed over 182 the entire splice length, and the splice resistance is inversely 183 proportional to the intercable contact length. This is confirmed 184 by the resistance results obtained for the Rutherford cable lap 185 splices produced with different overlap lengths (see Fig. 7).

186 The influence of single cut strands on the resistance of the 187 LHC busbar cable splices is negligible. The extreme case where 188 all strands are cut on both sides of the Rutherford cables along 189 the entire splice length causes a resistance of about $2.7 \mathrm{n} \Omega$.

190 The resistance results presented here have been obtained in 191 self-field with a huge critical current density margin of the $192 \mathrm{Nb}-\mathrm{Ti}$ superconductor. The application of external fields influ193 ences the resistance of internal magnet splices because of the 194 additional $\mathrm{Cu}$ magnetoresistance, and in case the critical current 195 density is exceeded in some strands by a current redistribution. 196 The resistance of a bridge splice can be estimated from the 197 resistance of a lap splice produced with the same cable, and 198 the intercable contact areas. Unlike lap splices, bridge splices 199 allow to interconnect cables without any cable bending, which 200 is important when brittle superconductors need to be connected.
With a bridge splice a layer jump inside a $\mathrm{Nb}_{3} \mathrm{Sn}$ magnet 201 maybe possible. Further studies are needed to understand the 202 performance of the different splice layouts in high applied 203 fields.

Because of the strong field dependence of the critical current 205 density of $\mathrm{Nb}-\mathrm{Ti}$ and $\mathrm{Nb}_{3} \mathrm{Sn}$ superconductors, there is always a 206 huge margin in terms of critical current density for splices that 207 are outside the high field region of a magnet. The critical current 208 density of high temperature superconductors like Bi-2212 is 209 only relatively weakly related to the applied field, and if such 210 conductors are exploited at their full potential the $I_{c}$ margin 211 in self-field will be relatively small, so that the splice pro- 212 duction and non-destructive splice tests will require particular 213 attention.

\section{ACKNOWLEDGMENT}

We are grateful to M. Pozobon and O. Kalouguine for the 216 production of the splices and to S. Prunet from the CERN 217 Cryolab for the current decay constant measurements.

\section{REFERENCES}

[1] L. Evans, Ed., The Large Hadron Collider: A Marvel of Technology. 220 Boca Raton, FL, USA: CRC Press, 2009.

[2] Z. Charifoulline, K. Dahlerup-Petersen, R. Denz, A. Siemko, and 222 J. Steckert, "Splice resistance measurements in the LHC main 223 superconducting magnet circuits by the new quench protection system," 224 in Proc. IPAC, New Orleans, LA, USA, 2012, pp. 3557-3559. 225

[3] L. Belova, M. Genet, J.-L. Perinet-Marquet, P. Ivanov, and C. Urpin, 226 "Design and manufacture of the superconducting bus-bars for the LHC 227 main magnets," IEEE Trans. Appl. Supercond., vol. 12, no. 1, pp. 1305- 228 1309, Mar. 2002.

[4] S. Heck et al., "Non-destructive testing and quality control of the 230 LHC main interconnection splices," IEEE Trans. Appl. Supercond., to be 231 published.

[5] A. Jacquemod, A. Poncet, F. Schauf, B. Skoczen, and J. P. Tock, "Induc- 233 tive soldering of the junctions of the main superconducting busbars of 234 the LHC," CERN, Geneva, Switzerland, Sep. 4, 2003.

[6] C. Scheuerlein, G. Arnau, N. Charras, L. Oberli, and M. Taborelli, 236 "The thickness measurement of $\mathrm{Sn}-\mathrm{Ag}$ coatings on LHC supercon- 237 ducting strands by coulometry," J. Electrochem. Soc., vol. 151, no. 6, 238 pp. 206-212, 2004.

[7] C. Scheuerlein et al. "The effect of CuSn intermetallics on the 240 interstrand contact resistance in LHC superconducting cables," J. Appl. 241 Phys., vol. 97, no. 3, Feb. 2005, Art. ID. 033909.

[8] S. Heck, C. Scheuerlein, P. Fessia, and R. Principe, "The RRR of the 243 $\mathrm{Cu}$ components of the LHC main busbar splices," CERN TE-MSC, 244 Geneva, Switzerland, 2010, Tech. Note EDMS Nr. 1057918.

[9] LHC Cable Characteristics.

[10] R. Herzog and D. Hagedorn, "Inductive method to measure very small 247 joint resistances of superconducting wires," Div. LHC, CERN, Geneva, 248 Switzerland.

[11] S. Heck et al., "Electrical resistance and mechanical strength of LHC 250 busbar cable splices as a function of intercable contact length," CERN, 251 Geneva, Switzerland, CERN-ATS-Note-2011-074, 2011, EDMS Nr. 252 1159508.

[12] A. P. Verweij et al., " $1.9 \mathrm{~K}$ test facility for the reception of the supercon- 254 ducting cables for the LHC," CERN, Geneva, Switzerland, LHC Project 255 Rep. 246, Oct. 1998.

[13] D. Schoerling, S. Heck, C. Scheuerlein, S. Atieh, and R. Schaefer, "Elec- 257 trical resistance of $\mathrm{Nb}_{3} \mathrm{Sn} / \mathrm{Cu}$ splices produced by electromagnetic pulse 258 technology and soft soldering," Supercond. Sci. Technol., vol. 25, no. 2, 259 Feb. 2012, Art. ID. 025006

[14] R. Lutum, S. Heck, and C. Scheuerlein, "Electrical resistance of the 261 solder connections for the consolidation of the LHC main interconnec- 262 tion splices," IEEE Trans. Appl. Supercond., vol. 23, no. 3, Jun. 2013, 263 Art. ID. 3800404 


\section{AUTHOR QUERIES}

\section{AUTHOR PLEASE ANSWER ALL QUERIES}

AQ1 = Please provide publication update in Ref. [4]

AQ2 = Please provide publication update in Ref. [9].

END OF ALL QUERIES 